\title{
変性腰仙椎後彎に対する再手術例
}

一椎体後方短縮と ISF 法を使用して一

\author{
山口赤十字病院整形外科 \\ 大 石 正 信・佐々木 邦 雄 \\ 合 志光 平. 有 水 淳
}

\section{Reoperation for a casae of Lumbosacral Kyphosis-with Posterior Wedged Osteotomy and Intrasacral Fixation}

\author{
Masanobu Oishi, Kunio Sasaki, Kouhei Goushi, \\ and Jyun Arimizu
}

Department of Orthopaedic Surgery, Yamaguchi Red Cross Hospital

\begin{abstract}
We report a case of degenerative lumbosacral kyphosis for which posterolateral intervertebral fusion was first performed, but failed to relieve, severe back pain which the patient complained of. We performed posterior wedged osteotomy of L4 and fusion from L2 to S1 using the intrasacral fixation technique. We believe the previous operation failed because maneuvering only the disk region was not enough for improving kyphotic lumbosacral alignment. Intrasacral fixation with vertebral osteotomy is an effective method for the correction of degenerative lumbosacral kyphosis in that it can improve the kyphosis of the lumbar spine, as well as reduce the posterior tiliting of the sacrum which we regard as the 6th lumbar vertebrae. It is for this reason that we chose ISF. One year after the operation, the patient is free from the severe back pain which had prevented him from walking.
\end{abstract}

Key words: Degenerative Lumbosacral Kyphosis, Intrasacral Fixation

\section{はじめに}

我々は, 下位腰椎部の椎間板変性による前彎の減少 あるいは後弯形成とともに仙椎の後傾を示す変形に 対して, 変性腰仙椎部後弯と定義し, 病態ならびに 手術的治療について報告をしてきた。この病態は竹光 の定義した腰部変性後弯 (Lumbar Dgenerative Kyphosis：LDK）と同様の状態である ${ }^{8}$. 本疾患に おいては下位腰椎の前弯の減少と仙椎の後傾に伴う, 股関節の前方移動と過伸展を生じており, 正常な立位, 歩行姿勢が保てなくなる。この病態に対して手術的治 療を行うにあたっては, 股関節を中心とした腰仙椎の バランスの再獲得が重要であることを指摘してきだ-577).
今回我々は, 初回手術として後方よりの椎体間固定を 施行されるも，変形矯正不十分でかつ症状の持続した 症例に対して, 椎体後方骨きり短縮法と intrasacral fixation（ISF）法使用による矯正固定術を行い，良 好な結果を得たので報告する。

\section{症例}

57 才の男性.

現病歴: H9. 9 月より腰仙椎部の後弯変形が増強し 直立保持が困難となった。 H9. 11 月 L4-S1 の VSP 使用によるPLIF 施行されたが症状の改善なく， VSP 除去後 H11. 6 月当科初診した.

理学所見 : 著明な前傾姿勢であり立位歩行持続困難 


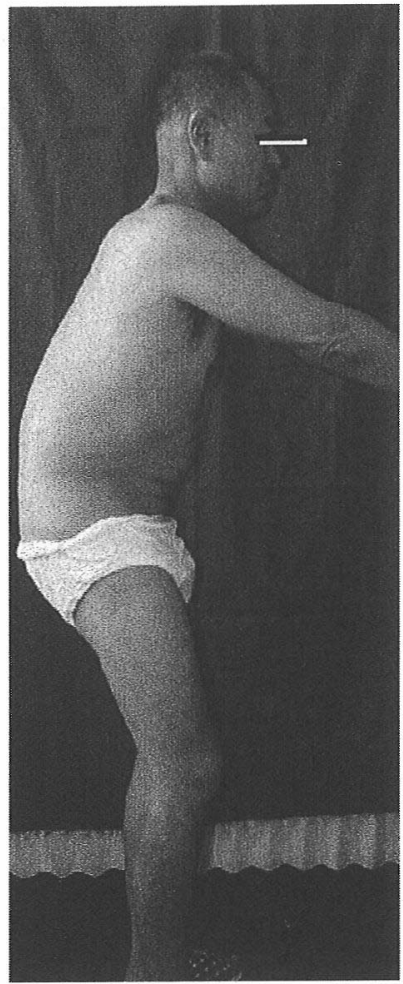

図 1 術前普通写真

であった（図 1)。神経学的な異常所見はなし，

術前 X 線所見: 腰椎前彎が 0 度，骨盤角が 42 度で あり，いわゆる腰仙椎部後弯変形の残存がみられた (図 $2 \mathrm{a} b \mathrm{c}$ ).

手術：Jackson tableを使用した腹卧位にて手術 を施行した．L3-4で L3 の下関節突起切除を含む広 範囲椎弓切除，L4 椎弓根経由 eggg shell 法による L4 椎体の楔状後方骨切り， L3-4 の椎間板切除を行っ た，骨きり後，Liberty system の oblique screw 使用による ISF 法ならびに Isola system によるL2, 3，5～仙椎の矯正固定を行った，後方短縮に際しては, 膝を屈曲しハムストリングの緊張をとり骨盤前傾をも たらしながら instrumetnationを施行した．L3-4 レ ベルにたいしては carbon cage 使用による後方椎体 間固定を施行，前回の後方椎体間固定の L4/5，L5/ $\mathrm{S} 1$ の AW spacer はそのまま残し，全範囲の骨移植 後側方固定を行った。

術後: L1/S 前弯角は 30 度を獲得でき骨盤角 30 度,
仙椎傾斜 28 度と仙椎の後傾の燆正も得られた（図 3, 4).

経過：術後 2 週より硬性装具装着下に下肢筋力, 歩 行，背筋のリハビリを開始した。

術後 4 週より階段昇降訓練を行った。 また術後 5 週 からは椅子上での前傾訓練や腹卧位伸展訓練，教養 椎部枕入訓練を行った．現在術後 1 年であるが腰痛も なく普通歩行可能で経過良好である.

考察

本症例の病態は下位腰椎（L4/5, L5/S1）の著明 な椎間板変性のみならず, 術前のレ線ならびに普通写 真でも明らかなように腰仙椎部の後弯を示す，我々の いう変性腰仙椎部後弯であった 変性椎間板の除去，椎間固定が行われ仙椎まで固定さ れるも，後弯の要因である前彎の減少の矯正が不十分 で, 股関節が前方に位置する腰仙椎部の後弯状態は解 消されなかった。このために，処置椎間板の癒合は獲 得されるも, 症状の改善なくかつ instrumentation failureを生じたと考えられる。

変性腰仙椎部後弯においてバランスを股関節を中心 として考えれば, 仙椎は第 6 腰椎となる。この後弯の 繑正に㧈いては，本症例の経過が示すように椎間板へ の操作のみでは有効な前彎の獲得は困難であり, 椎体 短縮法による矯正手技が必要となる。

我々は 1998 年よりこのような病態に対し後方侵入 による椎体短縮法を適応としてきた7”. 椎体短縮のレべ ルは椎間孔の解剖学的特徵を考慮し L4 で施行するこ とが大切と考えている。 また, 術中の短縮施行前に充 分な硬膜，神経根のスペースを確保して抢くことも， 神経麻疩の合併症予防に大切な事柄となる，腰椎後弯 変形に刘して同様の後方短縮後局所のみの固定による 矯正法の報告がみられるが, 我々は仙椎後傾の矯正な らびに後弯変形に対する矯正固定の面を考虑し仙椎ま で固定する方法としている。仙椎固定法として galveston 法と intrasavral fixation (ISF) 法が 現在考えられるが, 今回使用した ISF 法は術野の展 開も少なく，また仙椎回旋の矯正も術中可能であり， かつ生体力学的にも強固な固定法と考える. ISF 法の 実際に执いては，この方法の考案者であるJackson が開発した Liberty systemの oblique screw は有 用である11. 

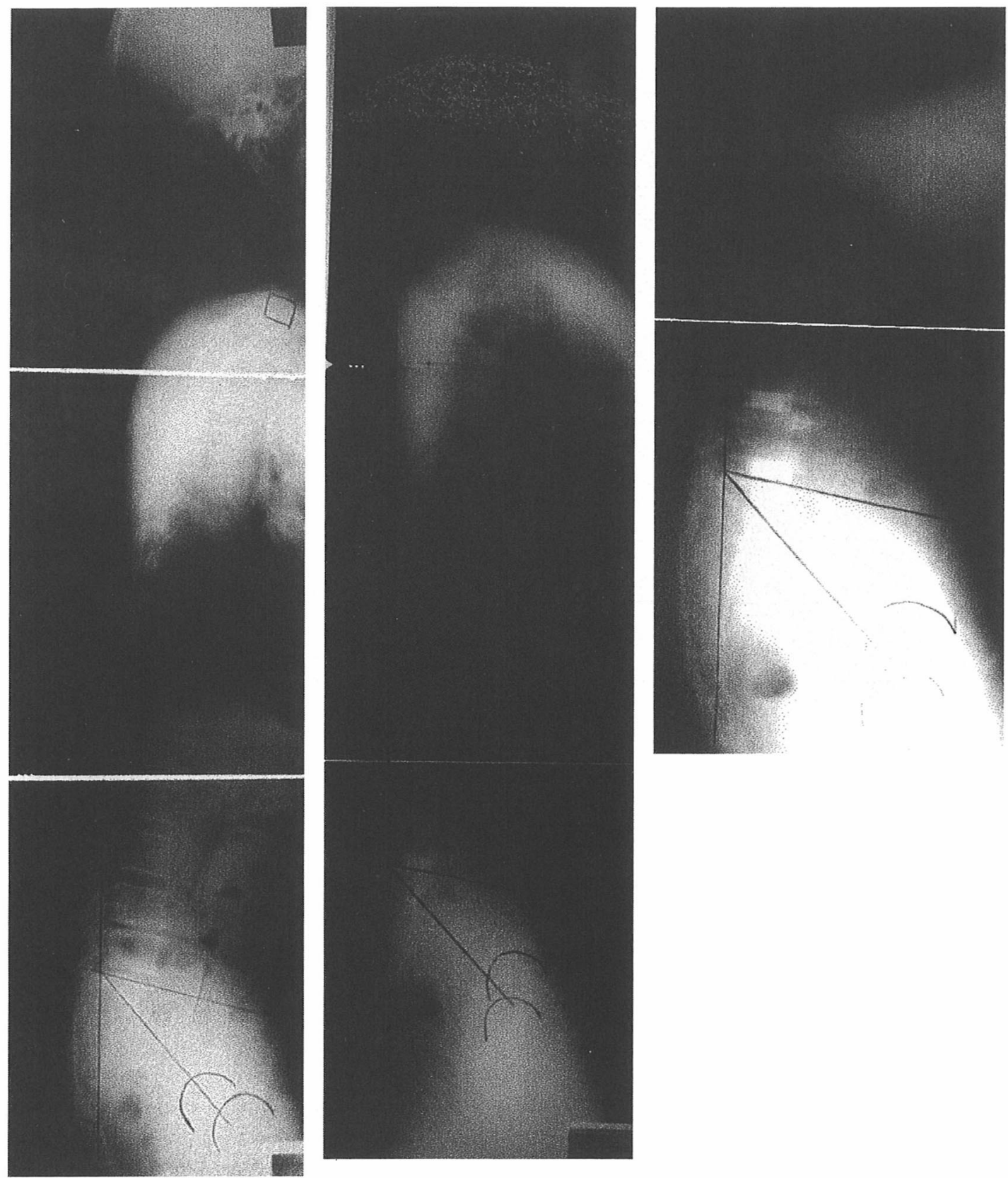

$\mathrm{a}|\mathrm{b}| \mathrm{c}$

図 2 a: 前医術前 $X$ 線

$\mathrm{b}$ : 当科術前 $X$ 線

$c$ : 当科術前 $X$ 線（腰仙椎拡大）

Pelvic Angle $(\mathrm{PA})=42^{\circ}$

Sacral Inclination (SI) $=15^{\circ}$

$\mathrm{L} 1 / \mathrm{S} 1$ Lordosis $(\mathrm{LOR})=0^{\circ}$

Sacral Translation (ST) $=96 \mathrm{~mm}$ （文献 2）参照） 

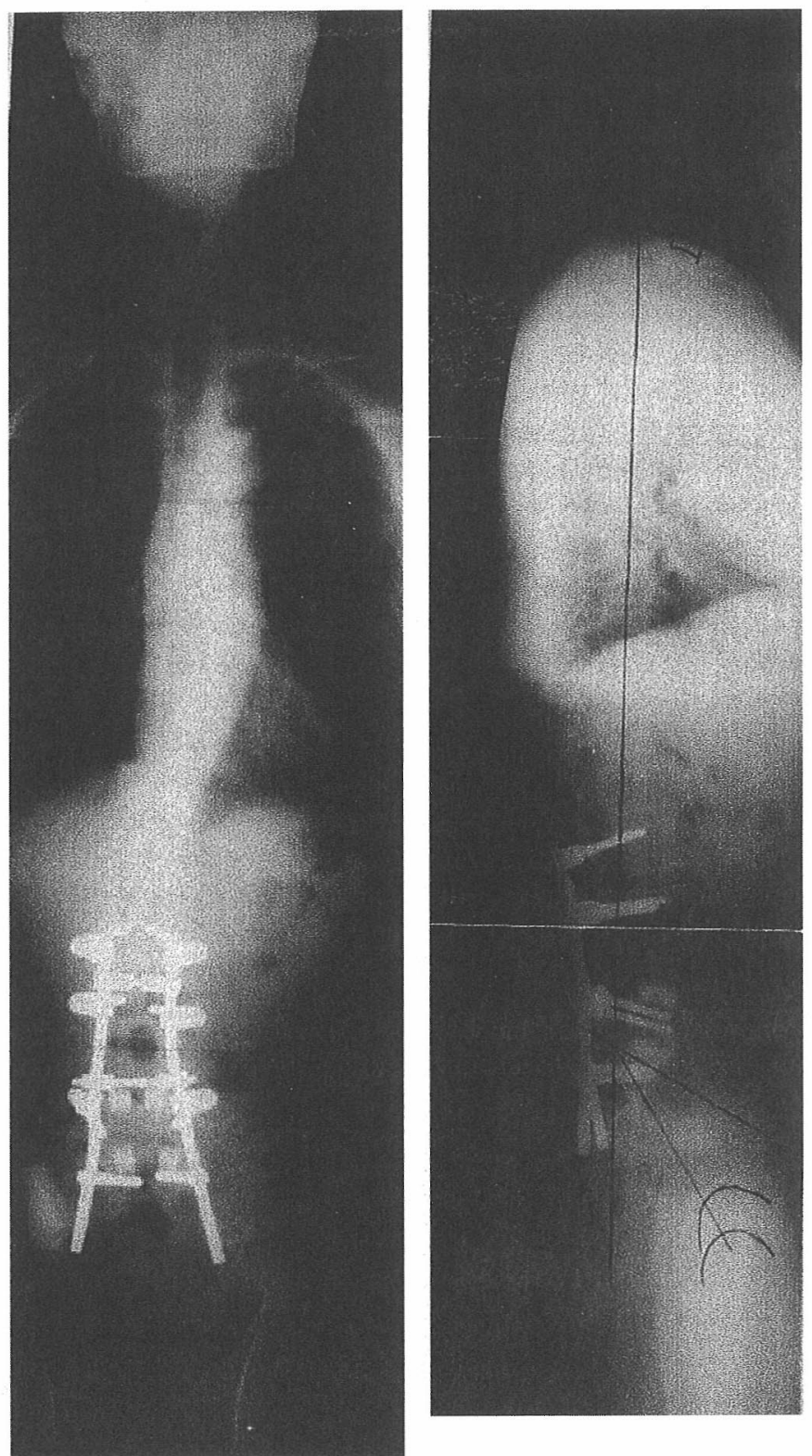

図 3 術後 X 線

$\mathrm{PA}=30^{\circ}$

$\mathrm{SI}=28^{\circ}$

$\mathrm{LOR}=30^{\circ}$

$\mathrm{ST}=70^{\circ}$ 


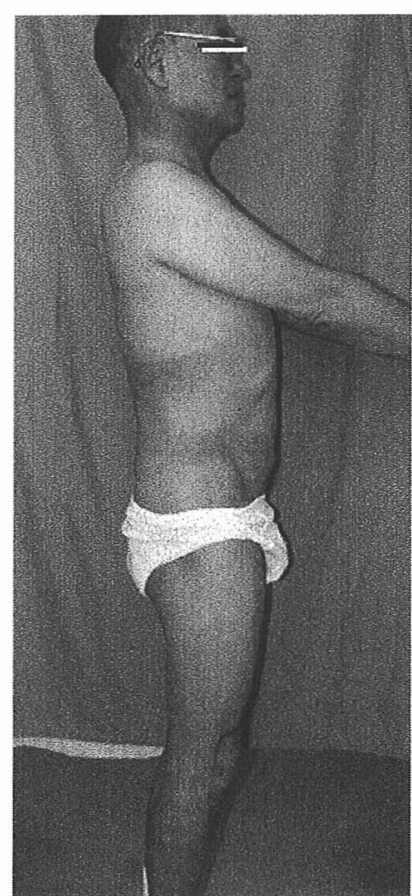

図 4 術後普通写真
変性腰椎例に刘する手術的治療においては, 腰椎の みの変形にとらわれず蓨柱全体のバランスを考慮した instrumentationの選択が必要なことを示した症例 を報告した。

\section{参 考 文 献}

1) Jackson, R.P.: Jackson sacral fixation and contoured spinal correction techniques. In Marguiles, J. Y., ed: Lumbosacral and Spinopelvic Fixation. Lippincot-Raven, Philadelphia. 357-379, 1996.

2) Jackson, R. P.: Spinal balance, lumbopelvic alignment around the hip axis, and positioning for surgery. State of the Art Reviews (Spine), $11: 33-58$, 1997.

3）大宮克弘, 佐々木邦雄：腰仙椎部後彎に対するIsola Galveston 法の問題点. 脊柱変形, $13: 175-177,1998$.

4) 佐々木邦雄他 : 中高蹫者の変性性腰仙椎部後彎の病態 と治療. 整外と災外, 43:1362-1365, 1994.

5）佐々木邦雄他：変性性腰仙椎後彎に対する手術的治療. 春柱変形, $10: 153-155,1995$.

6）佐々木邦雄, 大宮克弘 : 変性腰椎疾患における腰仙椎 部のアライメントの検討. 脊柱変形, $13: 50-53,1998$.

7）佐々木邦雄他：変性腰仙椎部後彎に対寸る後方短縮骨 切り術の経験. 整外と災外, 48:762-767, 1999 .

8）竹光義治他 : 高龄者の各種後彎と腰痛. 整, 災外, 36 : 901-907, 1993. 